\section{Are You Ready to Play Outside?}

\section{Jenna Nemec-Loise}

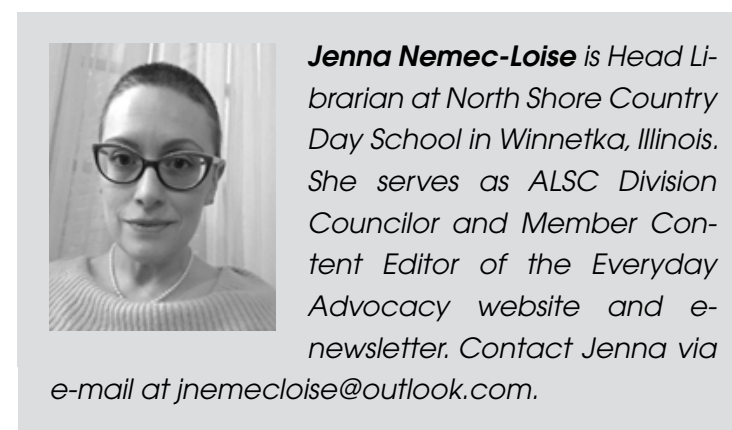

1 riends, this is my last Everyday Advocacy column for Children and

It's been awesome sharing my light-hearted (if not slightly irreverent) take on promoting the purpose and value of strong Youth Services, but it's time for me to move on so Everyday Advocacy can, too. As I take my leave, I hope you'll indulge me in a look back on the spark that kindled my advocacy flame-play.

\section{The Joy of Play}

When I was a little girl, I was ready to play outside because of my grandmother, Anna Nemec.

Grandma was made of sunshine, and my young days rose and set with her. Summers were especially glorious because we got to spend them in her flower and vegetable gardens, where I always had a special job to do.

Somehow Grandma always needed my expertise! How many roses had bloomed since last night? Could I help Grandpa fill the watering cans? Tell her again: Which ones are the weeds, and which ones are the new shoots coming up? Now why are these geraniums looking so droopy today? I loved Grandma's questions because, of course, I always had answers to match them.

Outdoor play was never a grander adventure than in the Wisconsin Northwoods, where my grandparents had a cottage in Eagle River. How many hours did Grandma and I spend wandering wooded trails watching for wildlife, gathering wild mushrooms, and playing I Spy? I was always at the center of Grandma's quiet games and gentle challenges, and she was the center of my world.

My grandma showed me the joy of play.

\section{The Dimension of Play}

When I was 10 years old, I was ready to play outside because of my mom, Kathy Nemec.

As leader of Great Blue Heron Council Girl Scout Troop \#349, my mom helped me and my five best friends-Kerri, Valerie, Chris, Jenny, and Jenniplay outside our own experiences with countless field trips and activities that got us thinking and doing in the world around us.

Mom was the epitome of "active learning and engagement" before the term even existed. As part of our World Neighbors badge, we baked, sang, and danced our way through Jamaica, live and direct from the halls of our church basement. 
Mom was the original intergenerational programmer. Holidays always included special visits to Menomonee Falls Nursing Home, where we sang songs, performed skits, and played games with folks eight decades our senior.

And Mom was always at the forefront of diversity education. We spent an entire day at the Curative Rehabilitation Center in Milwaukee learning about physical and developmental disabilities. Through various simulations led by the center's staff, we got a very real, albeit small, sense of what it might be like to live with limited mobility, sensory capacity, or cognitive function. Together we learned how to celebrate developmental differences and become more compassionate world citizens.

My mom showed me the dimension of play.

\section{The Power of Play}

When I was 17 , I was ready to play outside because of my high school drama coach, Mr. Cummings.

My teenage years were heavy and dark, an overcoat that didn't fit but couldn't be unworn. The word home was synonymous with volatile, unstable, and painful. The fights were unimaginable. The fear was all consuming. Emotional safety and comfort were ever elusive.

I wanted to play outside myself. I needed to play outside myself. Play—and quite literally, a play—saved me.

In my senior year, my friend Mary suggested I try out for the school play because she was, and she was, I quote, "sick and tired of Jenny Z. always getting the lead." She thought I had a shot, and she was right.

I didn't land the lead, but I still ended up with the best roleMrs. Banks opposite my friend Mike's Victor Velasco in Neil Simon's Barefoot in the Park. Rehearsals were at once fun and hard. Mr. Cummings pushed us. Mr. Cummings pushed me. "Where were you three years ago?" he asked with regret. Lost, I thought. But not anymore.

Each time I stepped on stage, the world around me fell away. In becoming someone else, I un-became the powerless girl who worried, who cried, who wondered if this is all there is for her. Life didn't hurt for Mrs. Banks. Maybe there was hope for me.

Mr. Cummings showed me the power of play.

\section{The Magic of Play}

When I grew up and became a professional librarian, a funny thing happened on a very ordinary morning at my branch.
I wasn't ready to play outside because of a mother and her chubby-cheeked, giggly baby.

She'd come in just after the library opened and sit with her son in our children's room, watching as other families arrived and dove right into our board books, wooden blocks, and LEGOs. As the play became increasingly more boisterous and exuberant (my favorite kind!), I took up my usual spot on the carpet so I could join in the fun with the infants, toddlers, and preschoolers visiting that morning.

As our regular families scattered in favor of lunches and naps, I heard a soft, "Excuse me." I turned to find this same mother still sitting at a table, her son squealing with glee and banging a blue plastic cup.

"Yes?" I said, smiling.

She paused for a full minute before asking her question: "Could you ... . do you think you can show me how to play with my baby?"

"Surprised" didn't even begin to cover it. I had a lifetime of positive play experiences to call upon and a dozen years in as an early childhood specialist, but in that moment, I was confounded. She had an adorable baby sitting on the table in front of her, laughing and cooing. Surely she knew how to play with him?

But this was genuine. For the very first time, I was being asked to play outside my comfort zone as a children's librarian and model what came quite naturally to me. Where would I even begin with a beginner?

The cup, I thought. Let's start there.

"I'd be happy to help!" I said.

As soon as I walked over to the baby, he laughed and handed me the cup in his hand. I smiled and thanked him, then pretended to drink from the cup, rubbing my belly and saying, "Mmmm!" Then I handed the cup back to him. To my delight as well as his mother's, he put the cup up to his mouth and squealed. He handed the cup back to me, and as you might imagine, we continued to trade delicious drinks and enthusiastic responses for several minutes.

In an instant, I became the adult - the grandma, the mom, the Mr. Cummings - who helps shape play experiences for a child, and maybe even for a child or a teen like me.

A mother and her baby showed me the magic of play. So how about you? 


\section{Are You Ready to Play Outside?}

Are you ready to play outside? (Oh, I'm sure Mo Willems won't mind if I borrow his title.)

Are you ready to play outside the reference desk and join in the fun of imaginative play with the youth and families who visit your library?

Are you ready to play outside the traditional roles of youth librarians by serving as a play facilitator and play mentor to parents and caregivers?

Are you ready to play outside your own professional service philosophy by reshaping it to include relationship-based approaches to play?

Are you ready to play outside expectations by championing the role of play in twenty-first-century learning, in STEAM-based education, in Common Core, and in an increasingly digital world?
Are you ready to play outside the library building by bringing messages about the value of play to stakeholders in your community?

Are you ready to play outside your comfort zone by advocating passionately and unapologetically for the critical role of play in the lives of all youth, from toddlers to teens?

Yes? Well, good. Because now it's down to brass tacks.

Be informed. Engage with your community. Speak out. Get inspired. And now more than ever, share your advocacy story. Write those elevator speeches so you can get out there and do this thing.

It's been my honor to be your Everyday Advocate. Go make me proud! ¿

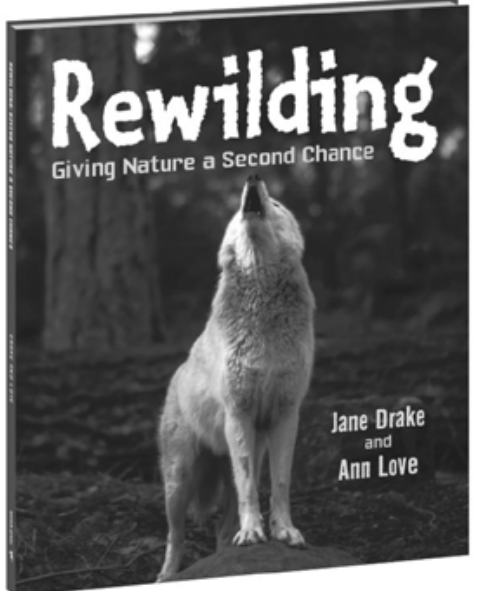

REWILDING: Giving Nature a Second Chance

by Jane Drake and Ann Love

"An excellent resource for those interested in nature."

-School Library Journal

"Clearly organized and accessibly written, this is a

welcome overview."

-Kirkus Reviews

Ages 9-12 / 978-1-55451-961-3 paper / 978-1-55451-962-0 hardcover

Read a sample chapter on our website

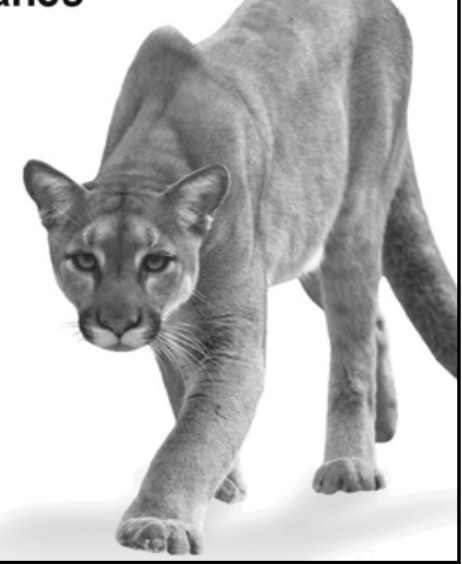

